ISSN:

Print - 2277-078X

Online - $2315-747 \mathrm{X}$

(c) FUNAAB 2018

Joumal of

Humanities, Social

Sciences and Creative Ants

\title{
PERCEPTION ON DATING, COURTSHIP AND MARRIAGE AMONG UNDERGRADUATES IN FEDERAL TERTIARY IN ST ITUTIONS IN OGUN STATE
}

\author{
1A.M. ARIYO, 1D.I. OSUNBAYO, 1J.T. ENI-OLORUNDA AND 2W.A.O AFOLABI \\ $*_{1, D}$ epartment of Home Science and Management, Federal University of A griculture, \\ Abeokuta, Nigeria \\ 2D epartment of Nutrition and Dietetics, Federal University of Agriculture, Abeokuta, \\ Nigeria afolabiwao@yahoo.com \\ *Comesponding Authormotunrayoariyo@yahoo.com Tel: +2348084623889
}

\begin{abstract}
The study examined the perception on dating, courtship and marriage amongst undergraduates in Federal Tertiary Institutions in Ogun State. The study adopted a survey design. The sample size consisted of 445 students using random sampling technique. The instrument for data collection was questionnaire constructed by the researchers. Results indicated that $57.8 \%$ were of the opinion that marriage shouldn't be an obligation as it is in our society, $77.5 \%$ agreed that to be adequately prepared for adulthood, dating must be practiced, the study also revealed that $97.1 \%$ agreed that courtship prepares individuals for marriage life. The study further indicated that there was a significant relationship between undergraduates perception on courtship and mother's educational level with a value of $\left(X^{2}=\right.$ 13.21. $P<0.05)$. The study concluded that dating helps in the development of adolescents but could pose dangers if not properly practiced, courtship is a structured relationship leading to a long lasting union. It is recommended that practices of sexual adventures a as a result of dating calls for family life education as it would equip young people with knowledge on dating.
\end{abstract}

Keywords: Perception, Dating, Courtship, Marriage, Undergraduates, Relationship

\section{INTRODUCTION}

Marriage is a relationship that unites a man and a woman. It is a contract requiring an agreement between two persons involved in the relationship. Arising from such an agreement is the desire to live together as husband and wife forever. It can be regarded as an institution ordained by God as well as by the culture of any society (Makinde, 2001).

Ever before a couple goes to the altar to exchange marriage vows, the man and the woman would have engaged in series of romantic activities to determine physical, social, emotional and attitudinal compatibility. This activity is to ensure that the partner is actually the fellow that he/ she would want to spend the rest of his/ her life with. Simply because in the earliest part of the heterosocial meeting, educational qualification, intelligence quotient (IQ) and financial/ socioeconomic status may not show on the forehead of the target, physical appearance is the first yardstick on which a first opinion either positive or negative can be formed. Certain 
phrases can be adopted like he or she 'looks cute, interesting to be with, seems nice, looks likable' and many others (Makinde, 2013). These assessments may pave way for dating, courtship and finally wedding.

The term dating has been defined as a dyadic interaction that focuses on participation in mutually rewarding activities that may increase the likelihood of future interaction, emotional commitment, and/ or sexual intimacy (Glass, Fredland, Campbell, Yona, Sharps and Kub, 2003).

It is difficult to define the concept of dating and courtship relationships as the ways in which people date and court have evolved over historical periods and vary considerably across cultures. The practice of courtship and dating originates primarily from Western societies and typically involves the process of selecting a marriage partner based on love, for the purposes of having children and raising a family. Lloyd (1991) points out that around the turn of the twentieth century courtship were a highly structured activity, centred on the woman's home, and largely controlled by the young woman and her family. In the early part of the twentieth century, dating became the centre of courtship as couples began to court in public. Accordingly, parental monitoring of courting couples declined, shifting the control of courting activities to the man (Lloyd, 1991). The decline of parental monitoring also allowed couples more opportunity for sexual intimacy. Although courtship has become more informal in contemporary Western societies, the romantic image of the heterosexual courting couple, which typically involves the idealisation of one's partner and the notion that love will sustain the relationship regardless of any difficulties the couple may encounter
(Lloyd, 1991), Marriage as an institution is facing a lot of problems in recent times globally and in the Nigerian contemporary society. The plausible reason for this has to do with the state of preparedness and perception of the institution by young people going into marriage and this in turn affects their adjustment capabilities later on leading sometimes to the breakdown of marriage.

This study therefore becomes imperative so as to enlighten the society on how youths perceive dating, courtship, marriage and their choice of marriage partners so as to help counsellors, parents and youths to encourage and educate young people as they journey towards marriage even from the early stage of their lives. On this note, the following deserves to be answered:

1. What perception do undergraduates have as regards dating and courtship?

2. What perception do undergraduates has as regards marriage?

\section{Research 0 bjectives}

1. To assess the perception of undergraduates on dating and courtship

2. To assess the perception of undergraduates on marriage

\section{Hypothesis of the Study} form was:

The study hypothesis stated in null

$\mathrm{H}_{0}$ : There is no significant relationship between undergraduate's socioeconomic characteristics and their perception on dating and courtship?

\section{METHODOLOGY}

\section{Population and Sampling Procedure}

Random sampling was adopted in selecting the respondents in the Federal Tertiary Insti- 
PERCEPTION ON DATING, COURTSHIP AND MARRIAGE AMONG ...

tutions in $\mathrm{Ogun}$ state. The target population were all students of federal tertiary institutions in Ogun State. Seven colleges/ schools were randomly selected from the institutions through balloting (with replacement), Afterwards, two departments were selected randomly through balloting (with replacement) from the 7 colleges/ school and ten students were selected using the stratified and systematic random sampling method from each departmental level where 260 undergraduates were sampled in Federal University of Agriculture, Abeokuta, 160 undergraduates in Federal Polytechnic Ilaro and 120 undergraduates in Federal College of Education, $O$ siele, which made a total of 540 respondents and 445 instruments were consequently used for the study.

\section{Instrumentation}

The instrument used for the study was a self developed questionnaire that elicited information on the socio-economic characteristics of the respondents, perception on marriage, perception on dating and perception on courtship.

\section{Validity and Reliability of Instrument}

To ensure that the instrument (i.e. the questionnaire) measured what it was expected to measure, face validity was carried out where draft copies were sent to a team of experts in Measurements and Evaluation. They ascertained that the items raised were unambiguous, clear and relevant.

A pilot study was carried out using the test retest method. The instrument was administered to 20 students of Moshood Abiola Polytechnic who did not participate in the main study twice within an interval of 2 weeks. The score of the two administrations were correlated using Pearson product moment correlation statistics. The reliability coefficient of the scales used were $(0.50$, $0.60,0.70$ ) which was used to determine coefficient of stability, which made the instrument to be considered reliable and stable over time and consequently was used for the study.

\section{RESULTS \\ Presentation of results \\ Undergraduates' Perception of Dating and Courtship: \\ Undergraduates' Perception of Dating:} The results in table 1 shows the perception on dating by undergraduates where $77.5 \%$ agreed that dating is an important process of growing up, $74.4 \%$ of the undergraduates agreed that the social and emotional growth of an individual can be enhanced through dating.

\section{Perception Score/ Index on D ating}

Results in Table 1(a) shows the categorisation of perception of respondents on dating where $55.0 \%$ had high/ favourable perception on dating, $29.7 \%$ had low/ unfavourable perception on dating and $15.3 \%$ had moderate perception on dating.

Undergraduates' Perception of Courtship: The results in Table 2 shows the perception of undergraduates on courtship which indicates that $77.1 \%$ disagreed that courtship is a waste of time as it does not guarantee a successful marriage life and 97.1\% agreed that courtship prepares individuals for marriage life. Furthermore, Courtship does not give individuals to catch fun like dating was agreed by $40.9 \%$ of the respondents while $81.8 \%$ disagreed that courtship is a traditional way of dating.

\section{Perception Score/ Index on Courtship}

Results in Table 2(a) shows the categorisation of perception of respondents on court- 
1A.M. ARIYO, 1D.I. OSUNBAYO, 1J.T.ENI-OLORUNDA AND 2W.A.O AFOLABI

ship where $79.3 \%$ had high/ favourable per- $11.0 \%$ had moderate perception on courtception on courtship, 9.7\% had low/ ship.

unfavourable perception on courtship and

Table 1: Perception of Undergraduates on Dating

\begin{tabular}{|c|c|c|c|c|c|c|}
\hline $\mathrm{S} / \mathrm{N}$ & Perception on Dating & $\begin{array}{l}\text { SA } \\
(\%)\end{array}$ & $\begin{array}{l}\mathrm{A} \\
(\%)\end{array}$ & $\begin{array}{l}\mathrm{D} \\
(\%)\end{array}$ & $\begin{array}{l}\mathrm{SD} \\
(\%)\end{array}$ & $\bar{x}$ \\
\hline 1. & $\begin{array}{l}\text { D ating is an important process of } \\
\text { growing up }\end{array}$ & 29 & 48.5 & 16.0 & 6.5 & 3.20 \\
\hline 2. & Dating is fun & 19.8 & 47.4 & 21.6 & 11.2 & 2.76 \\
\hline 3. & Dating is a welcomed idea & 25.4 & 54.6 & 11.2 & 8.8 & 2.97 \\
\hline 4. & $\begin{array}{l}\text { The social and emotional growth } \\
\text { of an individual can be enhanced } \\
\text { through dating }\end{array}$ & 21.8 & 52.6 & 16.2 & 9.4 & 2.87 \\
\hline 5. & $\begin{array}{l}\text { Dating partners play positive roles } \\
\text { in the development of adolescents }\end{array}$ & 20.7 & 52.6 & 20.9 & 5.8 & 2.87 \\
\hline 6. & $\begin{array}{l}\text { Dating gives many of the young } \\
\text { ones today the avenue to involve } \\
\text { themselves in sexual adventures }\end{array}$ & 30.8 & 46.5 & 16.2 & 6.5 & 1.98 \\
\hline 7. & $\begin{array}{l}\text { In today's Society, Unwanted } \\
\text { Pregnancies are as a result of da- } \\
\text { ting }\end{array}$ & 29.0 & 36.6 & 23.6 & 10.8 & 2.16 \\
\hline
\end{tabular}

Table 1(a): Perception Score/ Index on Dating

\begin{tabular}{llll}
\hline Perception on Dating & Score Range & Frequency & Percentage \\
\hline Unfavourable / Low & $11-26$ & 132 & 29.7 \\
Moderate & $27-28$ & 68 & 15.3 \\
Favourable / High & $29-44$ & 245 & 55.0 \\
\hline
\end{tabular}


Table 2: Perception of Undergraduates on Courtship

\begin{tabular}{|c|c|c|c|c|c|c|}
\hline $\mathbf{S} / \mathbf{N}$ & Perception on Courtship & $\begin{array}{l}\text { SA } \\
\text { (\%) }\end{array}$ & $\begin{array}{l}A \\
(\%)\end{array}$ & $\begin{array}{l}D \\
(\%)\end{array}$ & $\begin{array}{l}\text { SD } \\
(\%)\end{array}$ & $\overline{\boldsymbol{x}}$ \\
\hline 1. & $\begin{array}{l}\text { Courtship should be encour- } \\
\text { aged as it allows intending } \\
\text { couples to know each other } \\
\text { better }\end{array}$ & 64.8 & 31.2 & 2.7 & 1.3 & 3.59 \\
\hline 2. & $\begin{array}{l}\text { Courtship prepares individuals } \\
\text { for marriage life. }\end{array}$ & 62.9 & 34.2 & 1.8 & 1.1 & 3.59 \\
\hline 3. & $\begin{array}{l}\text { Courtship does not give indi- } \\
\text { viduals the avenue to catch fun } \\
\text { unlike dating }\end{array}$ & 9.7 & 31.2 & 42.0 & 17.1 & 2.66 \\
\hline 4. & $\begin{array}{l}\text { Courtship is not a guarantee of } \\
\text { successful marriage }\end{array}$ & $6.7 \%$ & $16.2 \%$ & $47.4 \%$ & $29.7 \%$ & 3.00 \\
\hline 5. & $\begin{array}{l}\text { Courtship is a traditional way } \\
\text { of dating }\end{array}$ & $8.1 \%$ & $10.1 \%$ & $51.0 \%$ & $30.8 \%$ & 3.04 \\
\hline
\end{tabular}

Table 2(a): Perception Score/ Index on Courtship

\begin{tabular}{lllc}
\hline Perception on Courtship & Score Range & Frequency & Percentage \\
\hline Unfavourable / Low & $7-16$ & 43 & 9.7 \\
Moderate & $17-18$ & 49 & 11.0 \\
Favourable / High & $19-28$ & 353 & 79.3 \\
& & & \\
\hline
\end{tabular}

Undergraduates' Perception of Marriage: Table 3 shows the perception of undergraduates on marriage where $71.2 \%$ disagreed to the statement that marriage is not necessary, 91.5\% agreed that Successful marriages influences a better society. However, $57.8 \%$ of the respondents agreed that marriage shouldn't be an obligation.

\section{Perception Score/ Index on Marriage}

Results in Table 3(a) shows the categorisation of perception of respondents on marriage where $63.6 \%$ had high/ favourable perception on marriage, $22.2 \%$ had low/ unfavourable perception on marriage and $14.2 \%$ had moderate perception on marriage. 


\section{Table 3: Perception of Undergraduates on Mamiage}

$\begin{array}{lllllll}\text { S/ N } & \text { Perception on Marriage } & \begin{array}{l}\text { SA } \\ \text { (\%) }\end{array} & \begin{array}{l}\text { A } \\ \text { (\%) }\end{array} & \begin{array}{l}\text { D } \\ \mathbf{( \% )}\end{array} & \begin{array}{l}\text { SD } \\ \mathbf{( \% )}\end{array} & \bar{x} \\ \text { 1. } & \text { Marriage is not necessary } & 12.8 & 16.0 & 23.8 & 47.4 & 3.06 \\ & \begin{array}{l}\text { Marriage is only important } \\ \text { for procreation }\end{array} & 7.6 & 16.0 & 46.3 & 30.1 & 2.99 \\ \text { 2. } & & & & & \\ \text { 3. } & \begin{array}{l}\text { Successful marriages influ- } \\ \text { ences a better society }\end{array} & 59.1 & 32.4 & 7.6 & 0.9 & 3.50 \\ \text { 4. } & \begin{array}{l}\text { Benefits of marriage can } \\ \text { be enjoyed without getting } \\ \text { married }\end{array} & 29.7 & 28.5 & 26.5 & 2.66 \\ \text { 5. } & \begin{array}{l}\text { Marriage should not be an } \\ \text { obligation. }\end{array} & 16.2 & 41.6 & 27.4 & 14.8 & 2.41\end{array}$

Table 3(a): Perception Score/ Index on Mamiage

\begin{tabular}{lllc}
\hline Perception on Marriage & Score Range & Frequency & Percentage \\
\hline Unfavourable / Low & $7-16$ & 99 & 22.2 \\
Moderate & $17-18$ & 63 & 14.2 \\
Favourable / High & $19-28$ & 283 & 63.6 \\
\hline
\end{tabular}

Relationship between Students Socioeconomic characteristics and Perception on Dating and Courtship: The relationship between undergraduate's socioeconomic characteristics and their perception on dating and courtship. Table 5 presented the result which shows that there is no significant relationship between under- graduates socio-economic characteristics and their perception on dating, however, table 6 shows that Mother's educational level with the value of $\left(\chi^{2}=13.21 . P<0.05\right)$ is significant. Therefore, it can be reported that there is a relationship between Mother's educational level and respondents perception on courtship. 
Table 4: Socio-economic Characteristics of the respondents

\begin{tabular}{|c|c|c|}
\hline Variables & Frequency & Percentages \\
\hline \multicolumn{3}{|l|}{ Father's Occupation } \\
\hline Trader & 90 & 20.2 \\
\hline Artisan & 22 & 4.9 \\
\hline Civil Servant & 256 & 57.6 \\
\hline Professional & 77 & 17.3 \\
\hline \multicolumn{3}{|l|}{ Mother's Occupation } \\
\hline Trader & 298 & 67.0 \\
\hline Artisan & 17 & 3.8 \\
\hline Civil Servant & 92 & 20.7 \\
\hline Professional & 38 & 8.5 \\
\hline \multicolumn{3}{|l|}{ Father's E ducational Level } \\
\hline None & 17 & 3.8 \\
\hline Primary School Leaving & 67 & 15.0 \\
\hline \multicolumn{3}{|l|}{ Certificate } \\
\hline S.S.C.E & 87 & 19.6 \\
\hline NCE & 43 & 9.7 \\
\hline $\mathrm{OND} / \mathrm{HND}$ & 94 & 21.1 \\
\hline B.Sc/ B.Agric/ B.Ed & 89 & 20.0 \\
\hline PG (PG D/ M.Sc/ MBA/ Ph.D ) & 48 & 10.8 \\
\hline \multicolumn{3}{|l|}{ Mother's E ducational Level } \\
\hline None & 34 & 7.7 \\
\hline Primary School Leaving & 78 & 17.5 \\
\hline \multicolumn{3}{|l|}{ Certificate } \\
\hline S.S.C.E & 97 & 21.8 \\
\hline NCE & 87 & 19.6 \\
\hline OND/HND & 74 & 16.6 \\
\hline B.Sc/ B.Agric/ B.Ed & 51 & 11.5 \\
\hline PG (PGD/M.Sc/ MBA/ Ph.D) & 24 & 5.3 \\
\hline \multicolumn{3}{|l|}{ Type of H ouse } \\
\hline One Room Apartment & 43 & 9.7 \\
\hline A Self Contained Apartment & 95 & 21.3 \\
\hline Boy's Quarters & 12 & 2.8 \\
\hline 3 bedroom apartment & 196 & 44.0 \\
\hline Duplex & 99 & 22.2 \\
\hline \multicolumn{3}{|l|}{ Ownership of the House } \\
\hline Rented & 107 & 24.1 \\
\hline Self Owned & 334 & 75.1 \\
\hline Government Quarters & 2 & .4 \\
\hline Others & 2 & .4 \\
\hline \multicolumn{3}{|c|}{ N umber of Cars owned by Parents } \\
\hline None & 146 & 32.8 \\
\hline 1car & 144 & 32.4 \\
\hline 2 cars & 111 & 24.9 \\
\hline
\end{tabular}


1A.M. ARIYO, 1D.I. OSUNBAYO, 1J.T.ENI-OLORUNDA AND 2W.A.O AFOLABI

Table 5: Relationship between socio-economic Characteristics and Perception on Dating

\begin{tabular}{lllll}
\hline Items & $\mathbf{(}^{\mathbf{2}} \mathbf{)}$ & $\mathbf{D f}$ & P-value & Decision \\
\hline Father's Occupation & 12.08 & 3 & 0.15 & NS \\
Mother's O ccupation & 9.27 & 3 & 0.32 & NS \\
Father's Educational level & 8.99 & 6 & 0.70 & NS \\
Mother's Educational level & 14.27 & 6 & 0.28 & NS \\
Type of House & 5.15 & 5 & 0.88 & NS \\
O wnership of House & 4.46 & 3 & 0.62 & NS \\
Number of Cars & 4.30 & 3 & 0.64 & NS \\
\hline
\end{tabular}

$\mathrm{P}<0.05$

Decision criteria is reject null hypothesis when $\mathrm{P}<0.05$

$\mathrm{df}=$ degree of freedom

$\mathrm{S}=$ Significant

NS $=$ Not Significant

Table 6: Relationship between socio economic Characteristics and Perception on Courtship

\begin{tabular}{lllll}
\hline Items & $\left(\boldsymbol{\chi}^{\mathbf{2}}\right.$ & Df & P-value & Decision \\
\hline Father's O ccupation & 4.70 & 3 & 0.32 & NS \\
Mother's O ccupation & 2.10 & 3 & 0.71 & NS \\
Father's E ducational level & 5.57 & 6 & 0.47 & NS \\
Mother's Educational level & 13.21 & 6 & 0.04 & $\mathrm{~S}$ \\
Type of House & 5.37 & 5 & 0.37 & NS \\
O wnership of House & 1.76 & 3 & 0.63 & NS \\
Number of Cars & 0.76 & 3 & 0.86 & NS \\
\hline P < 0.05 & & & & \\
D ecision criteria is reject null hypothesis when P < 0.05 & \\
df = degree of freedom & & & & \\
S = Significant \\
NS = Not Significant
\end{tabular}


PERCEPTION ON DATING, COURTSHIP AND MARRIAGE AMONG ...

\section{DISCUSSION}

It was revealed in this study that respondents believed that the social and emotional growth of an individual can be enhanced through dating. This is in line with the submission of Morgan and Zurbirggen (2007) that dating is a means of socialisation leading to personal and social growth, as an opportunity for companionship with members of the opposite sex. Similarly, Tang and Zuo (2000) submitted that dating is regarded as a means of personality development, a search for personal identity and individual worth and a striving towards maturity.

It was further revealed that respondents were of the opinion that dating partners plays positive roles in the development of adolescents which supports the submission that while early attachments relationships influence later relationships, each form of relationship (Parents, peers and romantic partners) has its own unique properties, dynamics and implications for adolescents development (G iordano đ.al., 2006). It was also got from this study that dating gives many of the youths today the avenue to involve themselves in sexual adventures and this supports the findings of Jewkes, e.al (2001) who suggest that for many adolescents, sexual experiences follow shortly after the first dating relationship. Taken together, it appears that dating is important in the development and identity formation of adolescents but at the same time could cause "damages" if not practiced appropriately.

The general submission of the respondents in this study is that courtship should be encouraged as it allows intending couples to know each other better, it prepares individuals for marriage life and it is a guarantee to successful. From the submission of the re- spondents, courtship is still regarded as a very important component before marriage. In addition, courtship has not in any way been modified to dating, as dating is casual and courtship remains a structured relationship which the goal of permanent union as respondents do not regard courtship as a traditional way of dating. Courtship is still remains relevant which negates the submission of Kass and Kass, (1999) that the erosion of courtship behaviour in western societies may correspond to a lack of preparation for marriage.

The respondents in this study agreed that successful marriages influences a better society, this connotes that the respondents are knowledgeable on the necessity and importance of successful marriages to a society. This indicates that values of marriage and family still exist. However, the respondents reported that marriage should not be an obligation as it is, which indicates a level of imitation of western culture. Most of the respondents disagreed that marriage is only important for procreation. A sides having and raising children, there are other importance of marriage according to Olayinka (1987) who identified three main purposes of marriage which are

1. To establish between a man and his wife a stable permanent association based on mutual affection of love and companionship.

2. To exercise the freedom and privilege of sexual relationship to the mutual satisfaction of the husband and wife.

3. To plan for the procreation of human species by establishing a house and a family with some children to perpetuate the ideals and values that the couples stand for. 
The relationship between undergraduate's socio-economic characteristics and their perception on dating and courtship. There was also a relationship between mother's educational level and perception on courtship among undergraduates, with possible explanation that educated mothers will be more enlightened and will have influence on their children's courtship practices as a pathway to marriage.

\section{CONCLUSION AND RECOMMEN DATION}

This study was carried out to determine the perception of undergraduates on dating, courtship and marriage. Findings demonstrated that dating helps an individual develop socially, emotionally and also helps prepare individuals for adulthood, although dating has other negative impacts like making young ones open to sexual adventures and bringing decline to academic performance. Courtship still remains an important component before marriage. Also, marriage is a very important institution that if handled properly would be a start to making the society a better one, although young people don't consider it an obligation which may be due to imitation of western culture. It was therefore recommended that practices of sexual adventures as a result of dating calls for family life education in tertiary institution. This will equip undergraduates with knowledge on dating and implications of wrong dating. Also, Youths should further promote and sustain the values of marriage for the improvement of the society.

\section{REFERENCES}

Giordano, P. C., Monica, A. L., Wendy, D. M., 2006. Gender and the Meanings of Adolescent Romantic Relationships: A Focus on Boys. Ammican Socidogical Reiew 71:260-287.

Glass, N., Fredland, N., Campbell, J., Yona, M., Sharps, P., Kub, J. 2003. Adolescent dating violence, prevalence, risk factors, health outcome and implications for clinical practice. Joumal of Obstenic, Gynaedog icandNematal nursing32(2), 227-238.

Jewkes, R., Vundule, C., Maforah, F., Jordaan, E. 2001. Relationship dynamics and teenage pregnancy in South Africa. Social SaienceandMediane, 52 (5), 733 - 744.

Kass, A.A., Kass, L.R. 1999. Proposing Courtship: First thing 96, 32: www.firstthings.com (accessed July 15, 2003) Lloyd, S.A. 1991. The dark side of courtship: Violence and sexual exploitation. FamilyRda tions, 40, 14-20.

Makinde, B.0. 2013. Effects of Husbands jealousy in marital stability among working intact couples in Lagos Metropolis. Reserch Jaumal in Organisational Psyddogy and Educa tional Studies, 2(5): 224.

Makinde, B.0. 2001. The effetiveness of two caunseling strateges on university student's percep tion of mamiageabiltiy. Unpublished $\mathrm{PhD}$ Thesis, University of Lagos.

Morgan, E.M., Zurbirggen, E.L. 2007. Wanting sex and wanting to wait: Young adult's accounts of sexual messages from 
PERCEPTION ON DATING, COURTSHIP AND MARRIAGE AMONG ...

first significant dating partners. Feminismand Tang, S., Zuo, J. 2000. D ating attitudes and Psydhdogy, 17 (4), 515 - 541. behaviour of American and Chinese College

Olayinka, M.S. 1987. Sex eduration andman- 78. Students. Thesaial saieneJaumal, 37 (1), 67 tal guidame Ikeja Lagos: Lattern House.

(Manuscipt received 18th June, 2018; accepted 18th Fenuary, 2019). 